\title{
Call for papers: \\ NJL Special Issue on Forensic Linguistics: European perspectives
}

The second issue of Volume 41 (autumn 2018) of the Nordic Journal of Linguistics will be a special issue devoted to forensic linguistics in the Nordic countries and in Europe. The issue will be edited by Tanya Karoli Christensen and Sune Sønderberg Mortensen.

Forensic linguistics is a fairly recent addition to the studies of language and the law, focusing on different aspects of language use in the legal process as well as the investigation and elucidation of linguistic evidence. The field has a strong empirical focus, typically analysing authentic case data for descriptive, theoretical or investigatory purposes. In other words, studies may be driven by linguistically relevant research questions or be solicited by practitioners such as police or defence lawyers who need an expert opinion on language data pertinent to an ongoing criminal case. Many descriptively-oriented studies also have clear applicational value, for instance in guiding the legal system to better handle language minority witnesses or victims of sexual assault.

The first use of the term 'forensic linguistics' is attributed to the Swedish linguist Jan Svartvik, who used it for his famous analysis of the so-called Evans Statements (Svartvik 1968). Svartvik showed that it was unlikely that the suspect, Timothy John Evans, had authored the most incriminating parts of his alleged confession to the murder of his wife and baby daughter. Unfortunately, this analysis came many years too late for Mr. Evans, who was sentenced to death and hanged in 1950. Nonetheless, Professor Svartvik's analysis broke new ground for the application of linguistics to real-world problems and paved the way for AUTHORSHIP ANALYSIS to become an integral part of the growing field's array of methods (see McMenamin 2002, Grant 2007, Stamatatos 2009). However, the methods used in authorship analysis, or text comparisons as they are also often called, are not widely agreed upon in the community. Indeed, serious critique has been raised by some scholars (e.g. Butters 2012), while others have called for a better integration of qualitative and computational methods (e.g. Solan 2013).

Particularly in English-speaking countries, forensic linguists have expressed increasing concern about how the legal rights of minority speakers are upheld (or not) throughout the legal system, from the issuing of warnings to suspects (e.g. Cotterill 2000, Berk-Seligson 2002; but see also van der Houwen \& Jol 2016) over 
the assessment of asylum seekers' demographic background (e.g. Eades 2005, Verrips 2011, Patrick 2012) to live interpretation during police interviews or in the courtroom (e.g. Berk-Seligson 1999, Nakane 2011). With the new migration patterns witnessed in Europe, problems of this nature ought to be further explored from a Nordic as well as a European perspective.

Civil cases of interest to linguists are, for example, trademark cases, where parties may dispute who has the legal right to a brand name or slogan (Shuy 2002), contract definitions (Shuy 2008) and product liability, where warning labels may give insufficient or unintelligible instructions on how to use or not use a possibly dangerous product (Shuy 2008).

We invite papers concerning any themes related to forensic linguistics, and we particularly welcome those addressing forensic linguistic questions from a Nordic or European perspective. Such themes include, but are not limited to, authorship analysis; (socio)linguistic profiling; analyses of forensic texts such as threatening letters, confessions, suicide notes, courtroom transcripts and police reports; emergency calls; speech comparisons; earwitnesses; intra- and interspeaker variation; courtroom interaction; interpretation issues in a legal context; language analysis for the determination of origin (LADO); trademark cases; contracts, legal and statutory definitions; and warning labels.

Submissions for papers should follow the style guide of $N J L$ available at http://journals.cambridge.org/NJL. The deadline for submitted papers is 2 November 2017. Papers should be sent to either of the following two guest editors:

Tanya Karoli Christensen
Department of Nordic Studies and
Linguistics
University of Copenhagen
2300 Copenhagen S
Denmark
tkaroli@hum.ku.dk

Tanya Karoli Christensen

Department of Nordic Studies and

Linguistics

University of Copenhagen

tkaroli@hum.ku.dk

\author{
Sune Sønderberg Mortensen \\ Department of Communication and \\ Arts \\ Roskilde University \\ 4000 Roskilde \\ Denmark \\ sunes@ruc.dk
}

\section{REFERENCES}

Berk-Seligson, Susan. 1999. The impact of court interpreting on the coerciveness of leading questions. Forensic Linguistics 6, 30-56.

Berk-Seligson, Susan. 2002. The Miranda warnings and linguistic coercion: The role of footing in the interrogation of a limited-English-speaking murder suspect. In Janet Coterill (ed.), Language in the Legal Process, 127-143. Hampshire \& New York: Palgrave Macmillan.

Butters, Ronald R. 2012. Retiring President's Closing Address: Ethics, best practices, and standards. Proceedings of the International Association of Forensic Linguists' Tenth Biennial Conference, 351-361.

Cotterill, Janet. 2000. Reading the rights: A cautionary tale of comprehension and comprehensibility. Forensic Linguistics 7(1), 4-25. 
Eades, Diana. 2005. Applied linguistics and language analysis in asylum seeker cases. Applied Linguistics 26(4), 503-526.

Grant, Tim. 2007. Quantifying evidence in forensic authorship analysis. International Journal of Speech, Language \& the Law 14(1), 1-25.

McMenamin, Gerald R. 2002. Forensic Linguistics: Advances in Forensic Stylistics. Boca Raton, FL: CRC Press.

Nakane, Ikuko. 2011. The role of silence in interpreted police interviews. Journal of Pragmatics 43(9), 2317-2330.

Patrick, Peter L. 2012. Language analysis for determination of origin: Objective evidence for refugee status determination. In Peter M. Tiersma \& Lawrence M. Solan (eds.), The Oxford Handbook of Language and Law, 533-546. Oxford: Oxford University Press.

Shuy, Roger W. 2002. Linguistic Battles in Trademark Disputes. Basingstoke \& New York: Palgrave Macmillan.

Shuy, Roger W. 2008. Fighting over Words: Language and Civil Law Cases. Oxford: Oxford University Press.

Solan, Lawrence M. 2013. Intuition versus algorithm: The case of forensic authorship attribution. Brooklyn Journal of Law and Policy 21(551), 551-576.

Stamatatos, Efstathios. 2009. A survey of modern authorship attribution methods. Journal of the American Society for Information Science and Technology 60(3), 538-556.

Svartvik, Jan. 1968. The Evans Statements. Gothenburg: University of Gothenburg.

van der Houwen, Fleur \& Guusje Jol. 2016. Negotiating the right to remain silent in inquisitorial trials. In Susan Ehrlich, Diana Eades \& Janet Ainsworth (eds.), Discursive Constructions of Consent in the Legal Process, 264-286. New York: Oxford University Press.

Verrips, Maike. 2011. LADO and the pressure to draw strong conclusions. International Journal of Speech, Language \& the Law 18(1), 131-143. 